\title{
Phytoplankton responses to freshwater inputs in a small semi-enclosed gulf (Gulf of Trieste, Adriatic Sea)
}

\author{
Alenka Malej ${ }^{1}$, Patricija Mozetič ${ }^{1}$, Vlado Malačič ${ }^{1}$, Senka Terzić ${ }^{2}$, Marijan Ahel ${ }^{2}$ \\ 'Marine Station Piran, National Institute of Biology, Fornače 41, SI-66330 Piran, Slovenia \\ ${ }^{2}$ Center for Marine Research Zagreb, Ruder Bošković Institute, Bijenička 54, 41000 Zagreb, Croatia
}

\begin{abstract}
Phytoplankton variations in response to freshwater inputs and water column structure in a shallow $(<25 \mathrm{~m}$ ) semi-enclosed Mediterranean gulf (Gulf of Trieste, Adriatic Sea) are described. Hydrographic profiles and in situ fluorescence were recorded at high resolution, while nutrients and phytoplankton were analysed at 5 pre-set depths. Analyses of the phytoplankton community structure were completed by determinations of the pigment pool using reverse-phase high-performance liquid chromatography and size-fractionated primary production. The phytoplankton standing crop, community structure and primary production were profoundly influenced by freshwater inputs and water column stratification. The water column was well mixed and supported modest phytoplankton concentrations during winter. A spring diatom bloom (Skeletonema costatum, Nitzschia spp., Chaetoceros spp.) developed in response to major freshwater input to the surface layer; a similar increase in diatoms (Rhizosolenia delicatula, R. fragilissima) followed October-November freshets. A shift from diatomdominated winter-spring phytoplankton to a flora with increased numbers of flagellates in the stratified water column during late spring-summer was reflected in the composition of accessory pigments [lower fucoxanthin: 19'-hexanoyloxyfucoxanthin ratio, an increase of chlorophyll $b$ (chl b) and peridinin concentration]. Primary productivity was correlated with chl a biomass and showed surface peaks in April and June. The 2 to $10 \mu \mathrm{m}$ phytoplankton contributed significantly to the total productivity in January and June, while on an annual basis the most important producers were $>10 \mu \mathrm{m}$. The smallest fraction $(<2 \mu \mathrm{m})$ seemed to contribute little, except in July. Our data indicate that the new production resulting from land-born nutrient inputs was the main cause of major phytoplankton blooms, while the nutrient supply from the bottom became comparatively more important during dry summer months.
\end{abstract}

KEY WORDS: Phytoplankton - Primary production - Nutrients - Freshwater inputs - Photosynthetic pigments . Adriatic Sea

\section{INTRODUCTION}

Over the last 2 decades, the coupling of estuarine and near-shore ecosystem dynamics and nutrient inputs from coasts, including the watershed, has received considerable attention due to possible links with eutrophication processes (Granéli et al. 1990, Fisher et al. 1992). It has been shown that distributions of nutrients, development of dense blooms and phytoplankton community succession respond to seasonal and interannual fluctuations in freshwater discharges (Jordan et al. 1991, Harding 1994), although these processes may vary among systems (Fisher et aỉ. 1988, Radach 1992). The conversion efficiency of introduced nutrients into biomass and the structuring effect on phytoplankton communities depend on timing and ratios of supplied nutrients (Gallegos 1992); however, quantitative and time-dependent relations between inputs and phytoplankton are still poorly understood (Malone et al. 1988). Moreover, in subsystems (subestuaries, smaller gulfs) the timing and relative magnitude of the biological responses depend on a combination of direct inputs of local origin and regional inputs to a hierarchically higher system (Gallegos et al. 1992). 
The Northern Adriatic, having a surface area of about $19000 \mathrm{~km}^{2}$ and a volume of $635 \mathrm{~km}^{3}$, is the northernmost protrusion of the Mediterranean Sea, which ends with the Gulf of Trieste (Fig. 1). The whole area is strongly influenced by rivers on the western coast with an approximate average, yearly discharge of $3600 \mathrm{~m}^{3} \mathrm{~s}^{-1}$ (Degobbis \& Gilmartin 1990), resulting in an estimated volume-specific discharge of $5.6 \mathrm{~m}^{3} \mathrm{~s}^{-1}$ $\mathrm{km}^{-3}$. The Gulf of Trieste has a surface area of about $600 \mathrm{~km}^{2}$, volume of $9.5 \mathrm{~km}^{3}$ and average freshwater input of $150 \mathrm{~m}^{3} \mathrm{~s}^{-1}$ (Olivotti et al. 1986a), giving an average volume-specific discharge nearly 3 times higher than the Northern Adriatic as a whole. The impact of river inputs on nutrient concentrations, primary production and phytoplankton dynamics has been extensively studied during last $20 \mathrm{yr}$ along the gradient off the Po River plume from the western to the eastern side of the Northern Adriatic (Franco 1973. Revelante \& Gilmartin 1976, Smodlaka 1986, Degobbis 1988, Marchetti et al. 1989, Degobis \& Gilmartin 1990), while the Gulf of Trieste has received less attention (Olivotti et al. 1986b).

The scope of our study was to analyse the effects of local freshwater inputs on phytoplankton dynamics in the Gulf of Trieste by using a combination of various approaches including determination of biomass and productivity of different size classes, community structure as well as composition of taxonomic pigment markers.

The study was a part of a larger project (Alpe-Adria, The Observatory of the Northern Adriatic) aimed at determining the factors leading to the formation of excessive gelatinous aggregates in the Northern Adriatic (Degobbis et al. in press)

\section{MATERIALS AND METHODS}

Study site. The study was carried out in the Gulf of Trieste (Fig. 1) from May 1989 to December 1993 with sampling conducted every 3 to $4 \mathrm{wk}$. However, our report concentrates on 1992, when, besides measurements at sea, data were available for freshwater inputs (daily river flows, rainfall; data courtesy of Hydrometeorological Survey of the Republic of Slovenia). The Gulf of Trieste is shallower along the northwestern side where the majority of freshwater enters the Gulf, whereas maximal depths reach about $25 \mathrm{~m}$ in the central part. The riverine inputs along the eastern coast are comparatively small, with an annual average flow $<10 \mathrm{~m}^{3} \mathrm{~s}^{-1}$ (Anon. 1985). Large temperature variations of 6 to $26^{\circ} \mathrm{C}$ in the surface layer and 6 to $20^{\circ} \mathrm{C}$ above the bottom and thermal stratification from May through September characterise the seasonal dynamics of the Gulf. The mean tidal range is about $100 \mathrm{~cm}$, but in extreme cases the changes in water level may reach over $150 \mathrm{~cm}$.

Field measurements, sample collection and analyses. At each station we performed CTD casts for salinity, temperature, dissolved oxygen, and fluorescence profiles (CTD fine-scale probe, University of Western Australia, and a Sea Tech Inc. fluorometer). Temperature and salinity data were used to calculate 'bulk' density gradient $(C)$ as follows:

$$
c=\left(\sigma_{\mathrm{Tb}}-\sigma_{\mathrm{Ts}}\right) / H
$$

where $\sigma_{\mathrm{Tb}}$ and $\sigma_{\mathrm{Ts}}$ are surface and bottom water densities, respectively, and $H$ is water column depth (m).

Secchi depth was measured with a $30 \mathrm{~cm}$ solid white disc.

Niskin bottles (5 l each) with a double rotating thermometer frame were used for water sampling at 5 depths $(0.5,5,10,15$ and $20 \mathrm{~m})$.

Concentration of inorganic nutrients were measured on unfiltered water samples using standard colorimetric methods (Grasshoff 1983).

Samples for enumerating phytoplankton were preserved with neutralised formaldehyde $1.5 \%$ final concentration). Micro- and nanoplankton were identified and counted on an inverted microscope using the technique of Utermöhl (1958); 100 or 50 fields were examined at $200 \times$ magnification. Epifluorescence microscopy was used to determine cell numbers of picoplankton $(<2 \mu \mathrm{m})$. Autofluorescent cyanobacteria retained on $0.6 \mu \mathrm{m}$ filter were counted in green excitation light at $1870 \times$ magnification.

Chlorophyll (chl) and carotenoid pigments were determined according to the modified method by Mantoura \& Llewellyn (Mantoura \& Llewellyn 1983, Barlow et al. 1993). Briefly, water samples (0.5 to 1 l) were fil-

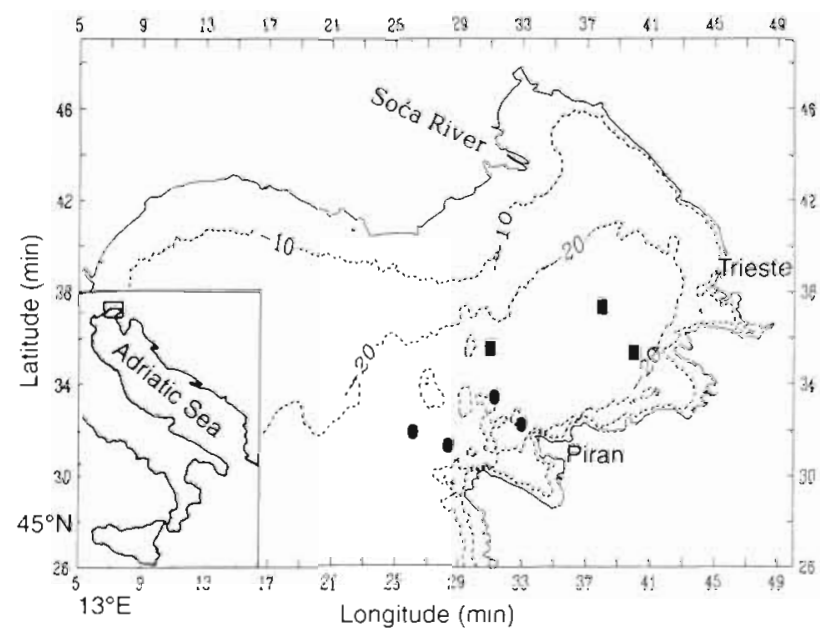

Fig. 1. Gulf of Trieste (Adriatic Sea) and sampling locations in the central ( $(\mathbf{)})$ and southeastern ( ) area 
tered through $47 \mathrm{~mm}$ Whatman GF/F filters and immediately frozen until analysed. Frozen samples were extracted in 4 to $10 \mathrm{ml}$ of $90 \%$ acetone using sonication and centrifuged to remove cellular debris. An aliquot $(300 \mu l)$ of clarified extract was mixed with $300 \mu \mathrm{l}$ of $1 \mathrm{M}$ ammonium acetate and $100 \mu \mathrm{l}$ injected in a gradient high-performance liquid chromatography (HPLC) system The HPLC system consisted of a Varian ternary gradient pump (Star 9010) and Spectra Physics UV/Vis spectrophotometric detector (UV2000-021). The system was equipped with a reverse phase $3 \mu \mathrm{m}$ $\mathrm{C}_{18}$ column (Pecosphere, $35 \times 4.5 \mathrm{~mm}$, Perkin Elmer). Solvent A consisted of $80 \%$ methanol and $20 \% 1 \mathrm{M}$ ammonium acetate, and solvent B contained $60 \%$ methanol and $40 \%$ acetone. A linear gradient from $0 \%$ $\mathrm{B}$ to $100 \% \mathrm{~B}$ for $10 \mathrm{~min}$ was followed by an isocratic hold at $100 \%$ B for 6 min. Chlorophylls and carotenoids were detected by absorbance at $440 \mathrm{~nm}$. Data collection and reprocessing utilised Spectra Physics PC1000 software.

Phytoplankton productivity was measured by the ${ }^{14} \mathrm{C}$ technique (Steeman Nielsen 1952). Water samples were taken from 5 depths $(0.5,5,10,15$ and $20 \mathrm{~m})$, poured into light and dark $75 \mathrm{ml}$ polycarbonate bottles and $6 \mu \mathrm{Ci}$ of $\mathrm{NaH}^{14} \mathrm{CO}_{3}$ per bottle was added. The samples were incubated in situ for $4 \mathrm{~h}$ around noon. In July and November only surface incubations were carried out. At the end of incubation, cells in different size classes were collected on $10 \mu \mathrm{m}, 2 \mu \mathrm{m}, 0.6 \mu \mathrm{m}$ and $0.2 \mu \mathrm{m}$ polycarbonate filters. Subsamples of unfiltered seawater and $0.2 \mu \mathrm{m}$ filtrate were also collected. The filters were placed in scintillation vials and acidified with $5 \mathrm{M} \mathrm{HCl}$ to remove residual $\left({ }^{14} \mathrm{C}\right)$ bicarbonate. Scintillation cocktail ( 5 or $10 \mathrm{ml}$ ) was added and the activity of samples measured on a Canberra TriCarb 2500 scintillation counter. Assimilation of carbon was calculated as described by Gargas (1975), considering $5 \%$ isotope discrimination, activity of added $\mathrm{NaH}^{14} \mathrm{CO}_{3}$ and inorganic carbon concentrations $\left(t \mathrm{CO}_{2}\right)$ at 5 depths calculated from salinity, temperature and $\mathrm{pH}$. Euphotic zone primary production was then calculated by integrating values between surface and depth $\left(z_{\text {eu }}\right)$ which was estimated from Secchi disc reading $\left(z_{\mathrm{SD}}\right)$ by using a simple formula $z_{\mathrm{eu}}=2.0 z_{\mathrm{SD}}$ (Preisendorfer 1986).

\section{RESULTS}

\section{Freshwater inputs, hydrographic and nutrient data}

The flow regime of the Soča (Isonzo) River, the main freshwater source to the Gulf of Trieste, is generally characterised by low flows in early winter and summer and high flows in early spring and autumn. Episodic short-lived pulses of high flow may occur in late spring

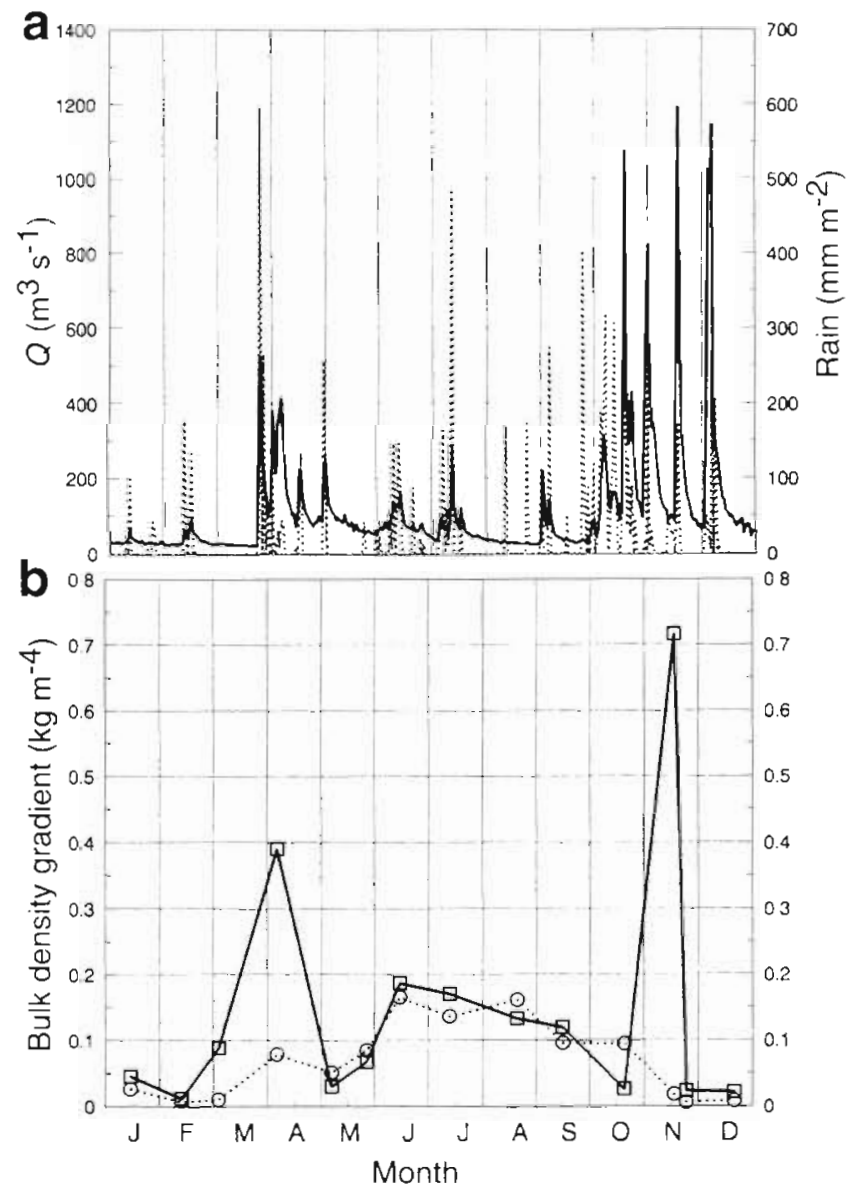

Fig. 2. (a) Discharge of the Soča River (-), precipitation at Portorož Meteorological Station $(\cdots \cdot)$. (b) Monthly means of 'bulk' density gradient for the central $(\square$; the 3 stations indicated by in Fig. 1) and southeastern area ( $O$; the 4 stations indicated by in Fig. 1) of the Gulf of Trieste during 1992

and summer as a result of local storms. Compared to previous years, the Soča discharge during winter 1992 was lower than average, with major flooding events in late March-April and in autumn (Fig. 2a). After the spring freshet, flow remained low until October for a few short-lived pulses in the beginning of June, midJuly and early September. The entire autumn period was characterised by higher than usual discharges. Although Soča River flow was ultimately controlled by watershed rainfall and to a lesser extent, as the 1992 winter was dry, by snow melting, the local rainfall events clearly contributed a significant portion of the freshwater inputs during summer (Fig. 2a). Together with gradually developing thermal stratification on a seasonal scale, these events regulated the 'bulk' density gradient of the water column (Fig. 2b). The water column appeared well mixed at all surveyed locations in January-February and in December. The density gradient was at its minimum during winter due to 
Table 1. Daily solar energy (monthly means $\pm \mathrm{SD}$ ) and spaceaveraged Secchi disc depth (means \pm SD) during 1992

\begin{tabular}{|lrr|}
\hline Month & Solar energy $\left(\mathrm{MJ} \mathrm{m}^{-2}\right)$ & Secchi depth $(\mathrm{m})$ \\
\hline Jan & $4.4 \pm 3.0$ & $8.0 \pm 1.5$ \\
Feb & $7.8 \pm 4.4$ & $19.0 \pm 6.0$ \\
Mar & $10.5 \pm 4.7$ & $11.0 \pm 1.5$ \\
A.pr & $18.2 \pm 6.9$ & $4.0 \pm 2.0$ \\
May & $23.3 \pm 4.2$ & $12.5 \pm 2.0$ \\
Jun & $21.6 \pm 6.2$ & $9.0 \pm 1.0$ \\
Jul & $23.6 \pm 4.2$ & $16.0 \pm 3.5$ \\
Aug & $21.7 \pm 3.1$ & $11.5 \pm 2.5$ \\
Sep & $18.5 \pm 5.1$ & $12.5 \pm 2.5$ \\
Oct & $6.9 \pm 4.2$ & $8.0 \pm 1.5$ \\
Nov & $4.4 \pm 2.4$ & $6.5 \pm 1.0$ \\
Dec & $3.2 \pm 2.0$ & $5.5 \pm 0.5$ \\
\hline
\end{tabular}

wind-driven surface cooling, mechanical stirring and low freshwater inputs. Melting of the snow from the Alpine hinterland and more intense rainfall during spring months created a buoyant surface layer spread-
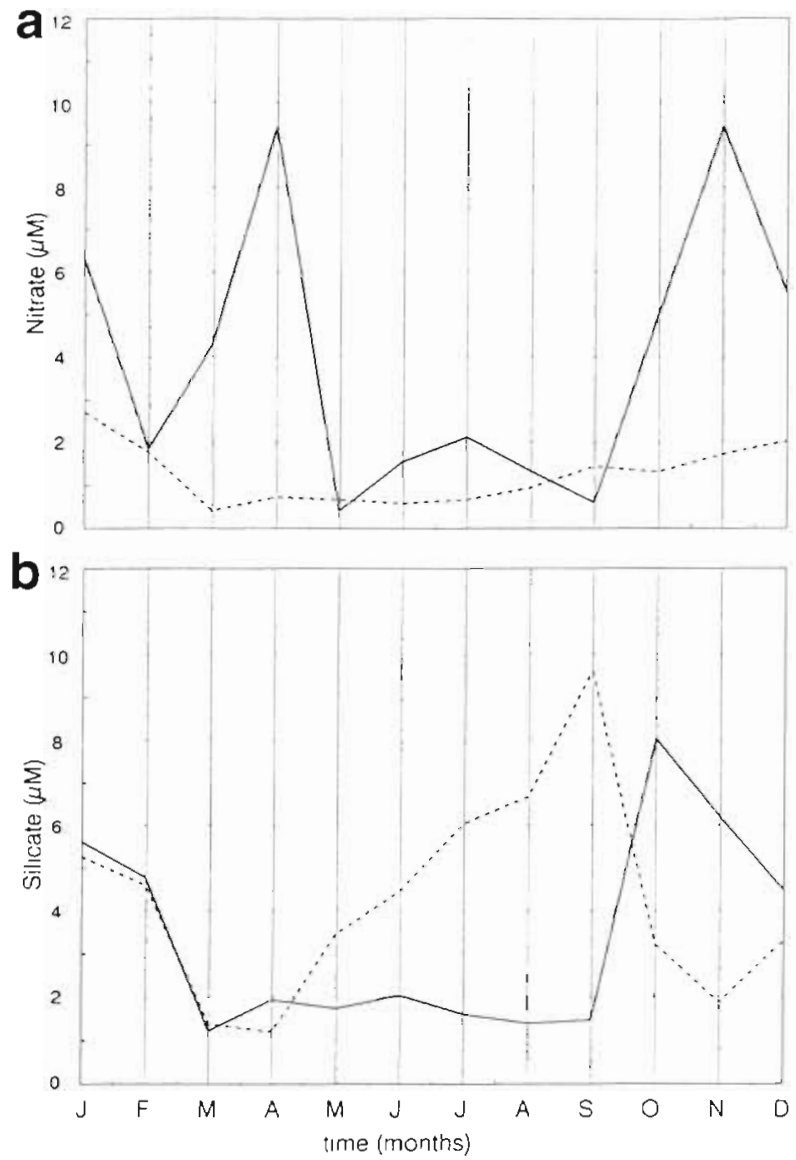

Fig. 3. Seasonal pattern of the mean (a) nitrate and (b) silicate concentration in surface (-) and bottom (--) water during 1992 ing from the northwestern towards the southeastern part of the Gulf and was not detected at southern stations. Vertical stability from April on was enhanced by downward heat flux at all locations and was the main factor influencing the density gradient at southern stations (Fig. 2b). Thermal stratification with deeper or shallower thermocline generally persists throughout the summer in the Gulf of Trieste. The autumn mixing reduced the stability of the water column, but it was enhanced again in late autumn months in the northwestern part due to large freshwater inflows. The water column appeared well mixed in December.

The daily energy received from solar irradiance (Table 1) increased from a daily average of $4.4 \pm 3.0 \mathrm{MJ}$ $\mathrm{m}^{-2}$ in January to $20 \mathrm{MJ} \mathrm{m}^{-2}$ from May through August. By October, total daily radiation decreased significantly to an annual minimum $3.2 \pm 1.9 \mathrm{MJ} \mathrm{m}^{-2}$ in December. Water transparency as Secchi depth ranged from 4 to $28 \mathrm{~m}$ with lowest mean values in April and December, and the highest in February and July (Table 1)

Nutrient concentrations (2.61 to $5.72 \mu \mathrm{M}$ nitrate, 0.24 to $2.72 \mu \mathrm{M}$ ammonium and 3.25 to $6.2 \mu \mathrm{M}$ silicate) were rather high throughout the water column in January-February, with a total inorganic nitrogen species/silicate ratio $\left(\sum N_{\text {in }} /\right.$ Si) of $1.2 \pm 0.4$ in surface water
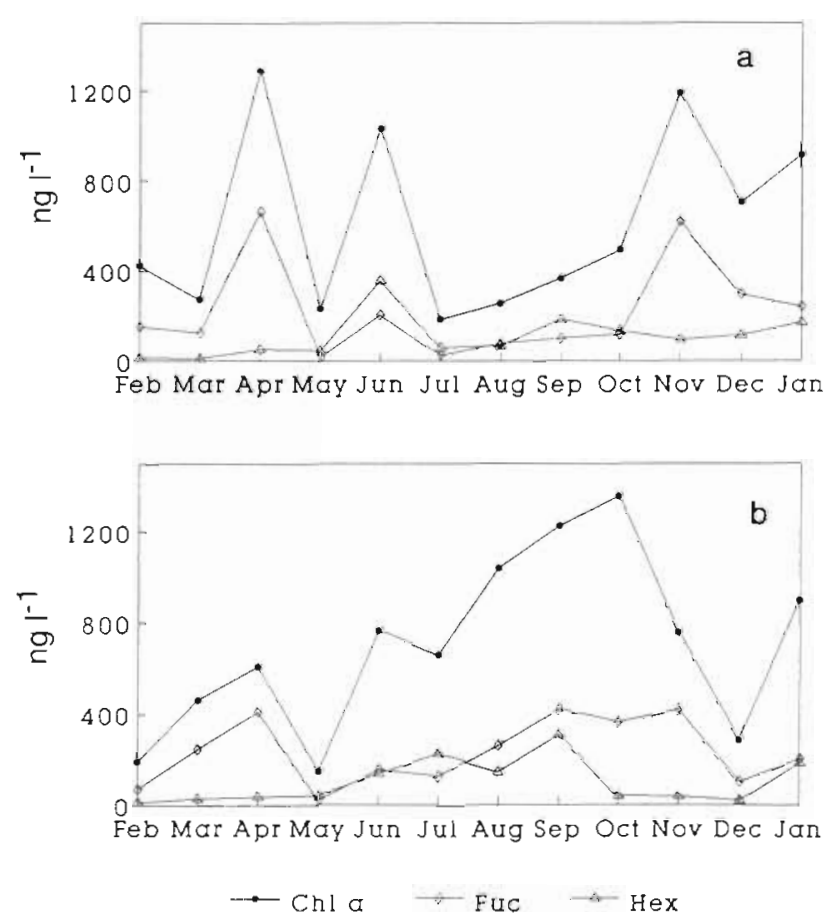

Fig. 4. Seasonal variations in phytoplankton pigment composition during 1992: chlorophyll a (•), fucoxanthin (0), and 19'hexanoyloxyfucoxanthin ( $\Delta$ ) in (a) surface and (b) bottom water during 1992 


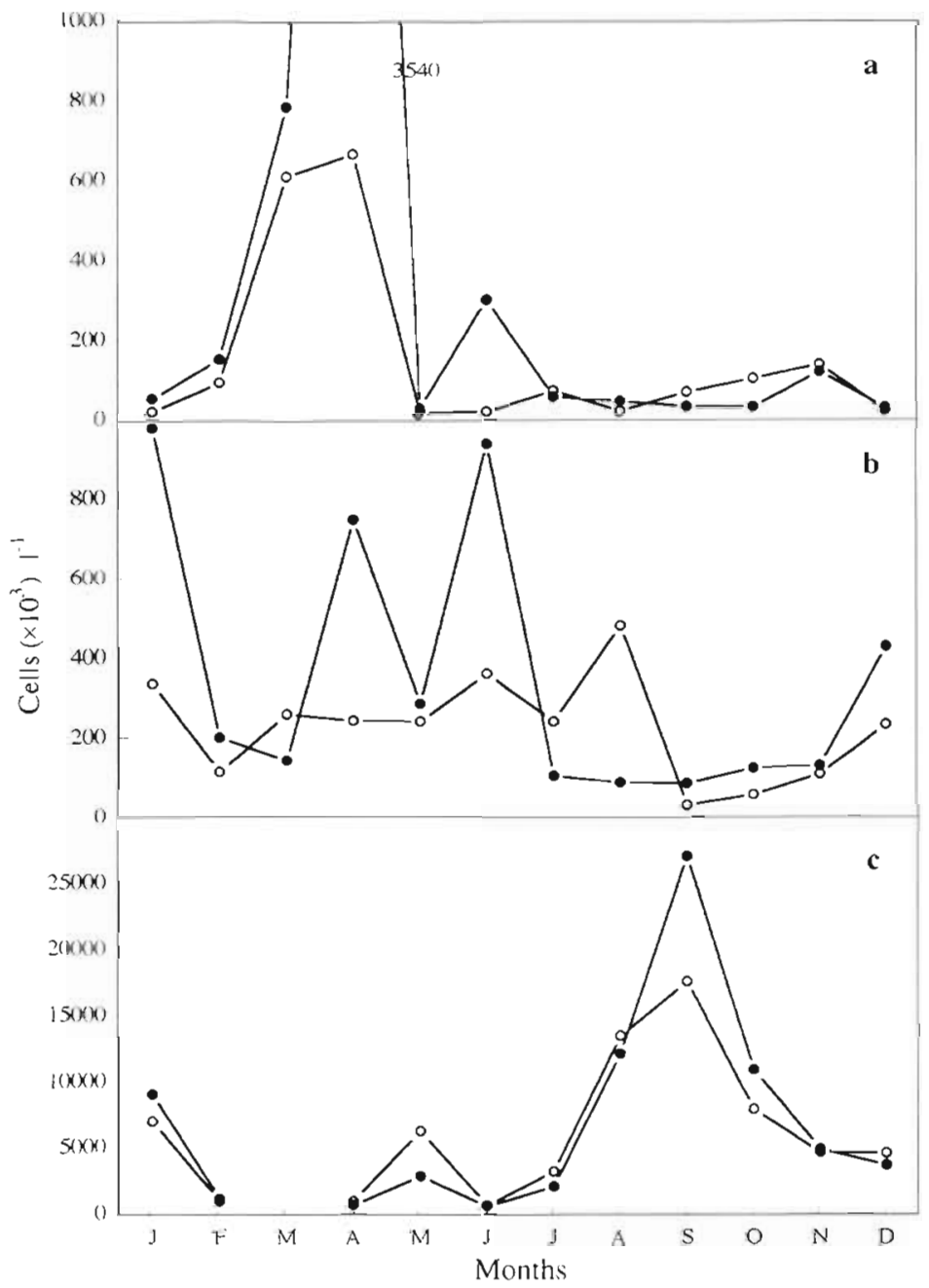

Fig. 5. Seasonal pattern of size-fractionated phytoplankton during 1992 (a) $>10 \mu \mathrm{m}$, (b) 2 to $10 \mu \mathrm{m}$, (c) $<2 \mu \mathrm{m}$ in surface ( $)$ and bottom (o) water

contrast, Si concentrations remained low throughout the spring-summer except in the bottom layer, where concentration peaks in August-September reached $>8 \mu \mathrm{M}$. Autumn mixing of the water column and high freshwater inflow in late October-November reintroduced nutrients to the surface layer, resulting in high nitrate $(>15 \mu \mathrm{M})$ and silicate $(>4 \mu \mathrm{M}$ ) concentrations (Fig. 3), followed by a marked drop in December.

Seasonal cycle and depth profiles of phytoplankton biomass, size distribution and productivity

Winter-spring variations of chl a concentrations were characterised by low winter values and a pronounced surface maximum in April (Fig. 4). Fucoxanthin-containing phytoplankton were most prominent not only in the surface chl a maximum but throughout the water column. The $>10 \mathrm{\mu m}$ size fraction prevailed in the phytoplankton (Fig. 5), and microscopic counts confirmed diatoms as the dominant group in the surface and the bottom layers (Fig. 6). The increase in phytoplankton abundance during March-April was accompanied by a sequential decline in silicate and nitrate concentrations (Fig. 3), and the spring diatom bloom collapsed by May when chl a values $<450 \mathrm{ng} \mathrm{l}^{-1}$ were measured at all sampling stations and depths. Increased phytoplankton biomass and a major change in phytoplankton size and species composition were found in June. A shift from predominance of

and $1.2 \pm 0.3$ in the bottom layer (Fig. 3). The March-April freshets with peak Soča River flows up to $550 \mathrm{~m}^{3} \mathrm{~s}^{-1}$ produced a drop in surface salinity but high nitrate concentrations with a gradient from the northwestern (up to $15.12 \mu \mathrm{M}$ ) to the southeastern (2.07 to $8.65 \mu \mathrm{M})$ part of the Gulf. As a consequence, the surface $\sum \mathrm{N}_{2 \mathrm{n}} / \mathrm{Si}$ ratio increased from the January-February mean of $1.2 \pm 0.4$ to $3.7 \pm 0.3 \mathrm{in}$ March and to $7.8 \pm$ 5.1 in April. The low salinity - high nitrate layer was confined to the upper $5 \mathrm{~m}$, while the water column below this depth was characterised by nitrate and silicate concentrations $<2 \mu \mathrm{M}$ (Fig. 3, see also Fig. 7b) and $\sum \mathrm{N}_{\mathrm{m}} / \mathrm{Si}$ ratios from 0.8 to 2.1 . Reduced freshwater inputs from April on, and high uptake as indicated by increased chl a values in April (Fig. 4a), were reflected in reduced nutrient levels. Small, yet significant, episodic freshwater inputs in June and July caused by local storms introduced new nitrogen into the Gulf. In diatoms in the winter-spring period towards nanophytoflagellates (Fig. 5) was reflected in a gradual increase of $19^{\prime}$-hexanoyloxyfucoxanthin (19'-hex), which became the most abundant accessory pigment in June (Fig. 4). During summer relatively low phytoplankton abundance and biomass (<500 ng chl a $\mathrm{l}^{-1}$ ) were measured in the surface layer, whereas values of 500 to $1400 \mathrm{ng} \mathrm{chl} \mathrm{a} \mathrm{l}^{-1}$ were determined in bottom waters. In October-November elevated inputs of nutrients due to heavy rain over the whole Soča River watershed, and autumn mixing of the water column were followed by increased phytoplankton biomass in the surface layer. The diatom contribution increased from $<20 \%$ of total phytoplankton abundance during summer to $>45 \%$ in November, and the most abundant species were Rhizosolenia fragilissima and Chaetoceros spp. Fucoxanthin was the dominant accessory pigment associated with the November chl a 


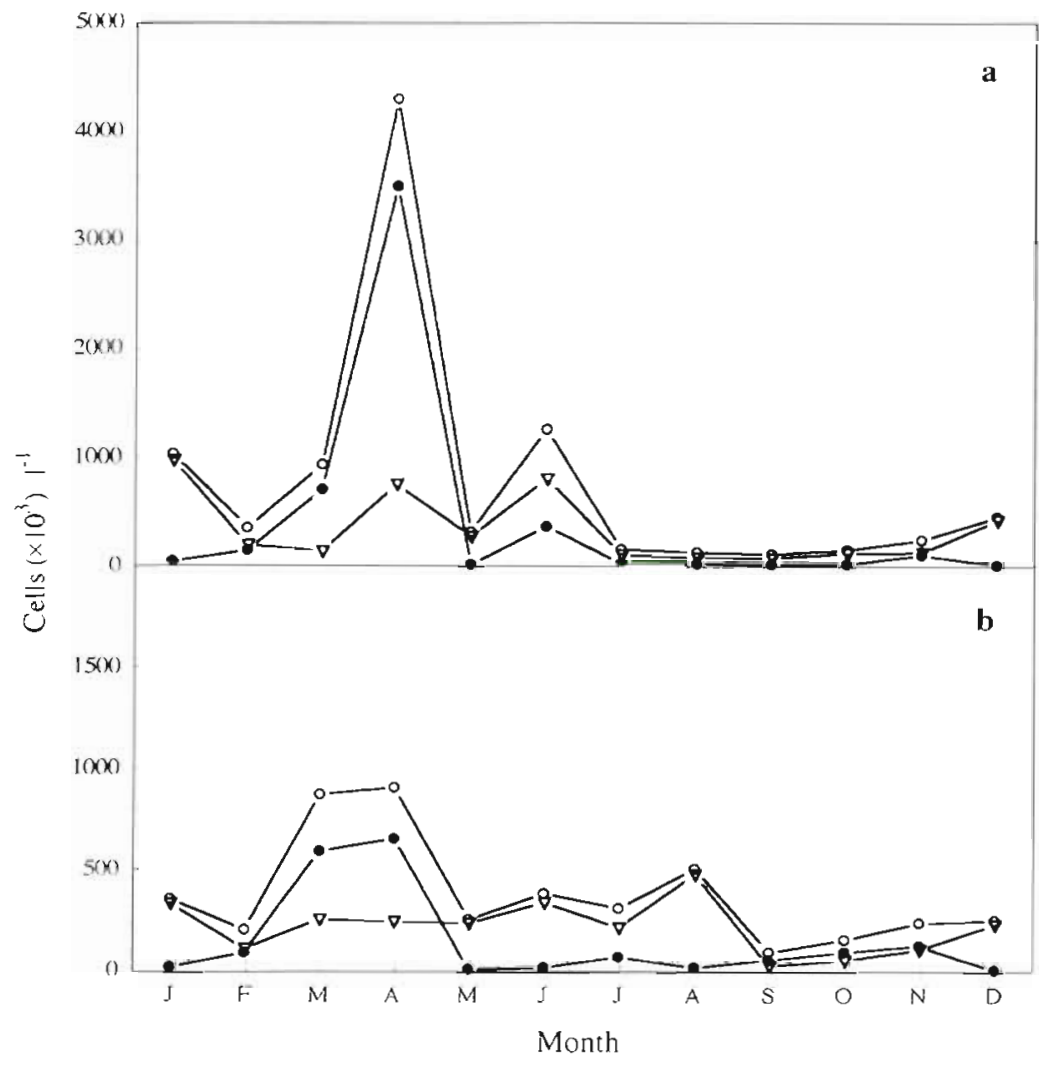

Fig. 6. Seasonal variations in phytoplankton abundance during 1992: total $(0)$, diatoms ( $\bullet$ ) and nanoflagellates $(\nabla)$ in (a) surface and (b) bottom water

costatum and Chaetoceros spp. Fucoxanthin was the main accessory pigment during the whole winter-spring period throughout the water column and exhibited a marked surface peak in April (Figs. 4a \& 7).

A CTD/fluorescence depth profile in June (Fig. 8) showed a stratified structure of the water column with higher fluorescence at the surface and the maximum at the bottom of the thermocline layer. The vertical distributions of chl a and accessory pigments in June (Fig. 9a) revealed that in the surface layer $19^{\prime}$. hex (274 to $\left.357 \mathrm{ng} \mathrm{l}^{-1}\right)$ was the most abundant one, but fucoxanthin (140 to $257 \mathrm{ng} \mathrm{l}^{-1}$ ), peridinin (46 to $88 \mathrm{ng} \mathrm{l}^{-1}$ ) and chl $b$ (47 to $60 \mathrm{ng} \mathrm{l}^{-1}$ ) were also prominent. A secondary chl a peak at the bottom of the thermocline layer (Fig. 8) was characterised by a significantly different composition of accessory pigments than the surface layer as reflected by lower relative abundance of $19^{\prime}$-hex ( 81 to $172 \mathrm{ng} \mathrm{l}^{-1}$ ) and higher values of fucoxanthin (138 to $247 \mathrm{ng} \mathrm{l}^{-1}$ ), chl $b$ (81 to $157 \mathrm{ng} \mathrm{l}^{-1}$ ) and peridinin (37 to $\left.94 \mathrm{ng} \mathrm{l}^{-1}\right)$. A rather low peridinin: fucoxanthin ratio suggested that fucoxanthin-containing dinoflagellates (Jef-

maximum (Fig. 4), while significant amounts of $\mathrm{chl} b$ (up to $660 \mathrm{ng} \mathrm{chl} b^{-1}$ ) were also detected.

CTD/fluorescence depth profiles showed that the water column was well mixed during January-February with a low $\left(<0.5 \mu \mathrm{g} \mathrm{chl} \mathrm{a}^{-1}\right)$ and uniform distribution of the phytoplankton biomass. An exception was a localised diatom bloom (Thalassionema nitzschioides, Cerataulina pelagica, Rhizosolenia fragilissima) in the surface layer of the central part of the Gulf, recorded in February. A high fluorescence layer was detected in the same area near the bottom in March as well as in April (Fig. 7), and microscopic observations indicated a taxonomic composition similar to the surface February bloom. Due to the sampling scheme in which pigment characterisation was carried out only at 5 preset depths, we have no pigment fingerprint for this deep fluorescence maximum. The surface chl a maximum which occupied the majority of the Gulf in April was dominated by the diatoms Nitzschia delicatissima, Skeletonema frey et al. 1975, Rowan 1990) could be important. Microscopic examination of samples confirmed that nanophytoflagellates numerically dominated the 2 to $10 \mu \mathrm{m}$ size fraction (Fig. 5), while the $>10 \mu \mathrm{m}$ fraction was represented mainly by dinoflagellates (Gymnodinium spp., Prorocentrum micans, P. triestinum, Glenodinium sp.).

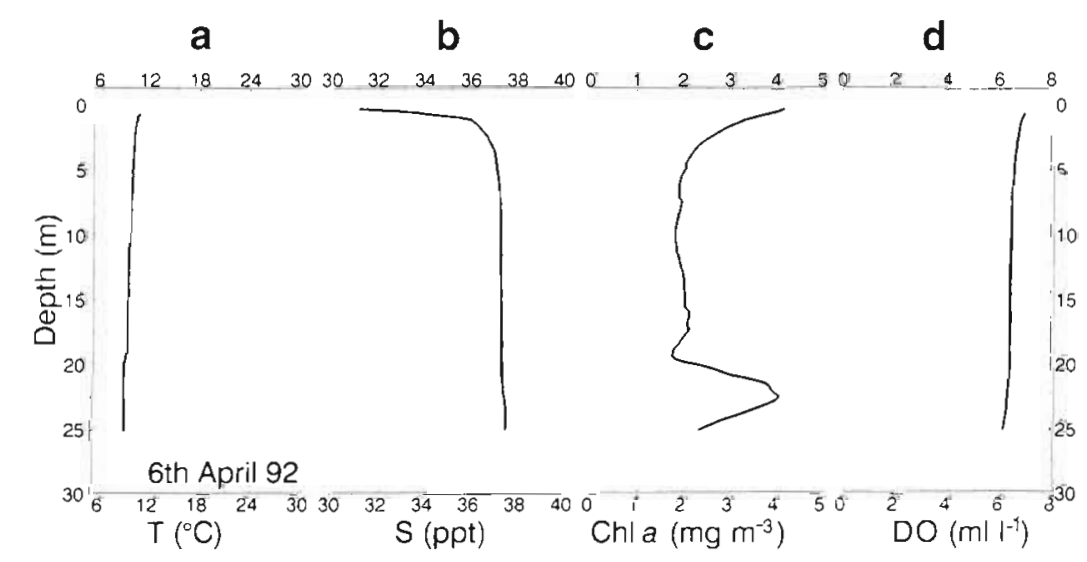

Fig. 7. (a) Temperature, (b) salinity, (c) in situ fluorescence and (d) dissolved oxygen (DO) depth profiles in April 1992 


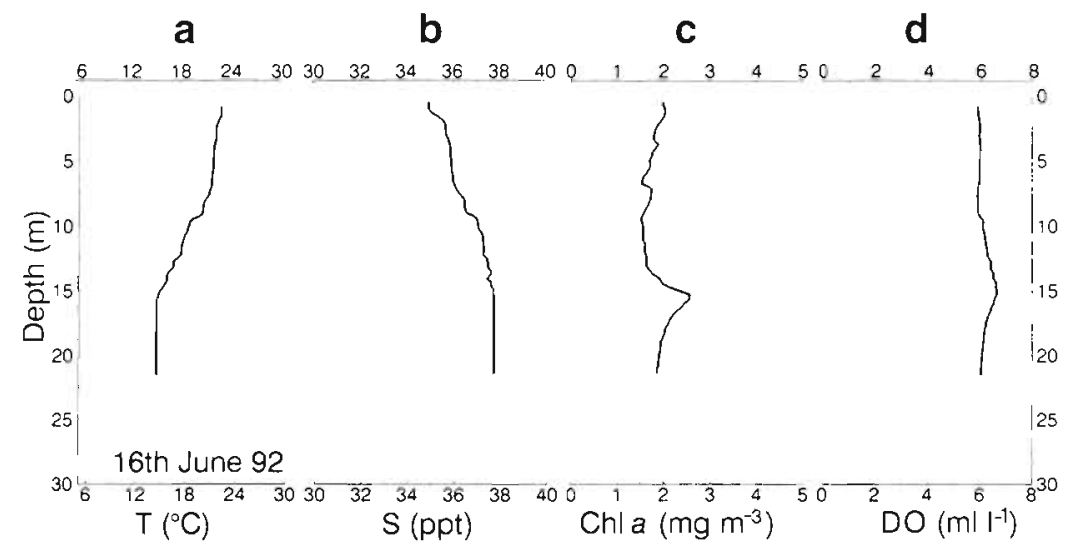

Fig. 8. (a) Temperature, (b) salinity, (c) in situ fluorescence and (d) dissolved oxygen (DO) depth profiles in June 1992

A '2-layer' system established during summer (Fig. 10) with an upper low nutrient - low chl a biomass layer, and a bottom mixed layer, where regenerated nutrients enabled the maintenance of moderate phytoplankton biomass (Figs. $4 \mathrm{~b} \& 10$ ). This situation with low phytoplankton abundance in surface waters, increasing slightly with depth, persisted until early autumn. From July to October the biomass gradually increased in the bottom layer (Fig. 4b). Throughout this period the water column was characterised by a low abundance of $>10 \mu \mathrm{m}$ cells, the prevalence of 2 to $10 \mu \mathrm{m}$ and $<2 \mu \mathrm{m}$ phytoplankton, with the latter fraction having its annual peak in September (Fig. 5), and slight predominance of $19^{\prime}$-hex over fucoxanthin. The pigment fingerprint of phytoplankton in October (Fig 9b), which is before complete water column mixing and large freshets, displayed a rather low chl a concentration and a moderate prevalence of 19' -hex over fucoxanthin in surface water, while the bottom layer was characterised by higher chl a biomass accompanied by strong predominance of fucoxanthin-containing phytoplankton (mainly diatoms Lauderia annulata and Rhizosolenia delicatula).

Table 2. Depth-integrated primary productivity (PP), chlorophyll a and chlorophyll a-specific total productivity (PP/chl a)

\begin{tabular}{|c|c|c|c|}
\hline Month & $\begin{array}{c}\mathrm{PP} \\
\left(\mathrm{mg} \mathrm{C} \mathrm{m}^{-2} \mathrm{~h}^{-1}\right)\end{array}$ & $\begin{array}{c}\text { Chl a } \\
\left(\mathrm{mg} \mathrm{m}^{-2}\right)\end{array}$ & $\begin{array}{c}\mathrm{PP} / \mathrm{chl} \mathrm{a} \\
\left(\mathrm{mg} \mathrm{C} \mathrm{mg} \mathrm{mg}^{-1} \mathrm{chl} a \mathrm{~h}^{-1}\right)\end{array}$ \\
\hline Jan & 4.9 & & \\
\hline Feb & 15.9 & 5.73 & 2.8 \\
\hline Mar & 99.2 & 7.54 & 13.2 \\
\hline A.pr & 54.2 & 7.43 & 7.3 \\
\hline Jun & 75.9 & 12.20 & 6.2 \\
\hline $\mathrm{Jul}^{\mathrm{a}}$ & 3.8 & 0.75 & 5.1 \\
\hline Oct & 12.1 & 6.74 & 1.8 \\
\hline Nov ${ }^{a}$ & 14.4 & 4.38 & 3.3 \\
\hline
\end{tabular}

The annual cycle of phytoplankton productivity was similar to that of the chl a biomass with the highest values in spring (Table 2). It should be mentioned that during July and November the productivity was assessed only by incubating phytoplankton at surface light conditions. ${ }^{14} \mathrm{C}$ productivity profiles showed noticeable peaks in the surface layer during April and June (Fig. 11) with a notable percentage of the production being due to cells $>10 \mu \mathrm{m}$. The 2 to $10 \mu \mathrm{m}$ size fraction contributed significantly to the total productivity in January and June. The smallest size fraction seemed to contribute little to total productivity. An exception was July when $<2 \mu \mathrm{m}$ production represented $>70 \%$ of the total $\left(1.19\right.$ to $\left.1.47 \mathrm{mg} \mathrm{C} \mathrm{m}^{-3} \mathrm{~h}^{-1}\right)$. Unfortunately, we lack productivity data during the period of maximal abundance of the $<2 \mu \mathrm{m}$ fraction (September). For October, data for total productivity only are available and showed a subsurface maximum and a pronounced decrease with depth, indicating low activity of the chl a peak in the bottom layer (Fig, 9b).
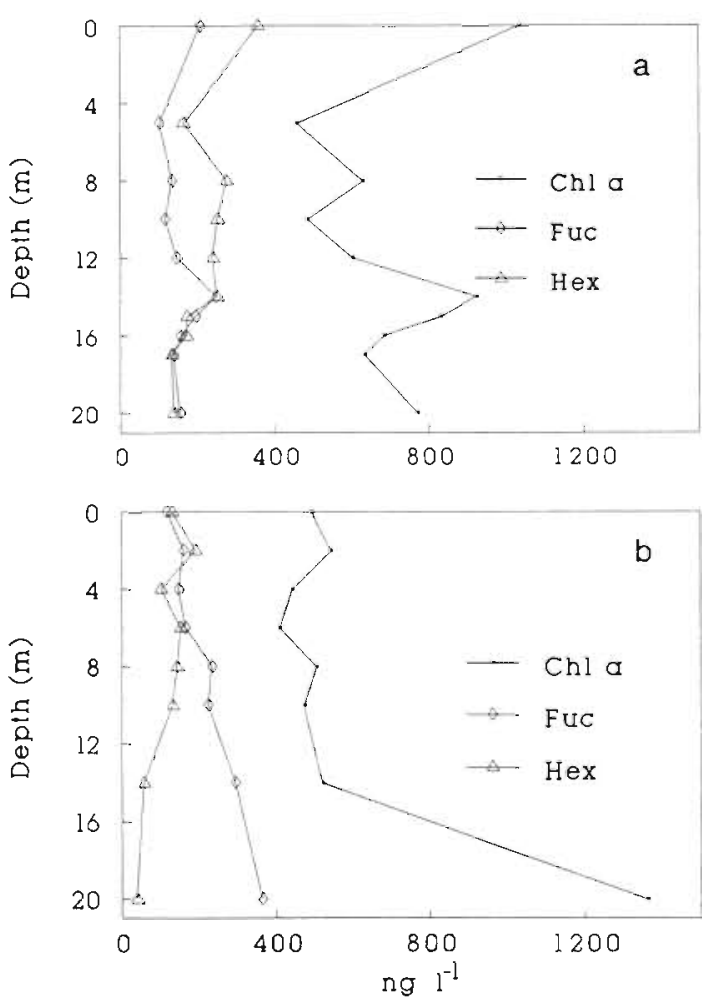

Fig. 9. Vertical distribution of phytoplankton pigments: chlorophyll a $(\bullet)$, fucoxanthin $(\diamond)$ and 19 '-hexanoyloxyfucoxanthin ( $\Delta$ ) in (a) June and (b) October 1992 


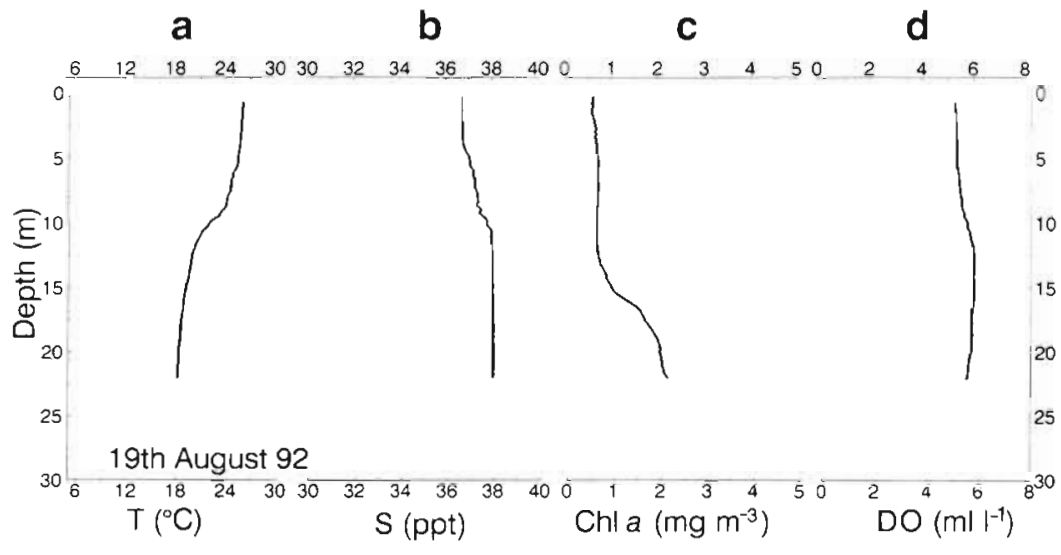

Fig. 10. (a) Temperature, (b) salinity, (c) in situ fluorescence and (d) dissolved oxygen (DO) depth profiles in August 1992

carried out in a rather shallow $(<25 \mathrm{~m})$ semi-enclosed coastal area that has 1 major freshwater source, the Gulf of Trieste. This Gulf has long been recognised as a Mediterranean region of comparatively high pelagic biomass at several trophic levels from phytoplankton, microbial plankton, zooplankton to fish. The extent of primary productivity, biomass and plankton community succession in the Gulf of Trieste has a strong seasonal pattern related to allochthonous inputs (Fonda Umani et al. 1992).

The results of our study suggest that the spring surface diatom bloom which covered the whole Gulf developed in response to major freshwater

Chl a-specific productivity ( $\mathrm{PP} / \mathrm{chl}$ a) for all size fractions (Table 2) varied broadly from 1.8 to $13.2 \mathrm{mg} \mathrm{C}$ $\mathrm{mg}^{-1} \mathrm{chl} \mathrm{a} \mathrm{h}^{-1}$ with lower values occurring during the colder part of the year. In general, chl a-specific productivity declined below $10 \mathrm{~m}$ depth.

The pigment fingerprint of phytoplankton in the maximal productivity layer suggested the important contribution of Prymnesiophytes (19'-hex; Arpin et al. 1976, Rowan 1990), diatoms (fucoxanthin) and to lesser extent green algae (chl $b$ ) in June and October. In April and November higher rates were measured in $>10 \mu \mathrm{m}$ than in smaller fractions, which is consistent with the observed increase of fucoxanthin-containing phytoplankton (Fig. 4a).

\section{DISCUSSION}

Investigations carried out in different estuarine systems have shown a major impact of freshwater influx on nutrient dynamics, biological structure and productivity. It has been indicated that variations in river flow, governed primarily by watershed rainfall, regulate the magnitude of estuarine primary production and periodicity of algal blooms, influence a seasonal shift in limiting nutrients and affect the extent of seasonal oxygen depletion in summer (Malone et al. 1988, Dortch \& Whitledge 1992, Fisher et al. 1992, Boyer et al. 1993, Mallin et al. 1993). The impact of freshwater input on phytoplankton dynamics is likely to vary among systems, although functional similarities may be expected. A generalisation of the influence of freshwater inputs on the biology of adjacent waters could be achieved by comparative analyses of marine ecosystems of different types and scales. However, there have been only a few studies of this kind outside major estuaries or large river plumes. Our study has been input during March-April. The freshwater-borne nutrients were introduced into the water column that was not yet thermally stratified and was rather unstable. The influence of freshwater was restricted to the upper $5 \mathrm{~m}$ layer and was distributed throughout the Gulf, except in the southeastern part. High phytoplankton biomass in that surface layer showed an increasing trend toward less saline waters as indicated by significant negative correlation between chl $a$ and salinity $\left(r^{2}=0.59\right.$ at salinities $\left.>20 \mathrm{ppt}\right)$. During this late winter-early spring period characterised by a high surface chl a biomass, we also measured high photosynthetic rates, indicating that in situ production rather than advection/accumulation was largely responsible for the observed biomass increase. The main part of the measured production was associated with the $>10 \mu \mathrm{m}$ size fraction. In this period the population was dominated by small- to medium-sized diatoms like Skeletonema costatum (up to $1.32 \times 10^{6}$ cells $\mathrm{l}^{-1}$ ) and Nitzschia spp. (up to $3.61 \times 10^{6}$ cells $^{-1}$ ) capable of fast growth with maximum in situ doubling rates of $3 \mathrm{~d}^{-1}$ (Furnas 1990). A similar increase of surface diatom biomass followed the OctoberNovember freshet. However, predominant species in this period were the larger forms, including Rhizosolenia delicatula, $R$. fragilissima and Chaetoceros spp., and chl a-specific productivity was lower than in March-April. The spring diatom bloom collapsed by the first $10 \mathrm{~d}$ in May (total phytoplankton abundance $<0.3 \times 10^{6}$ cells $\rfloor^{-1}$, when nitrate and silicate concentrations fell below $2 \mu \mathrm{M}$. The diatom contribution dropped below 15\% throughout the Gulf. Phytoplankton abundance remained low during the second half of May and increased following episodic freshwater input in early June. This input was primarily due to local storms and had a much smaller effect on surface nutrient concentrations than did the spring or 


$$
P P\left(m g C m^{-3} h^{-1}\right)
$$
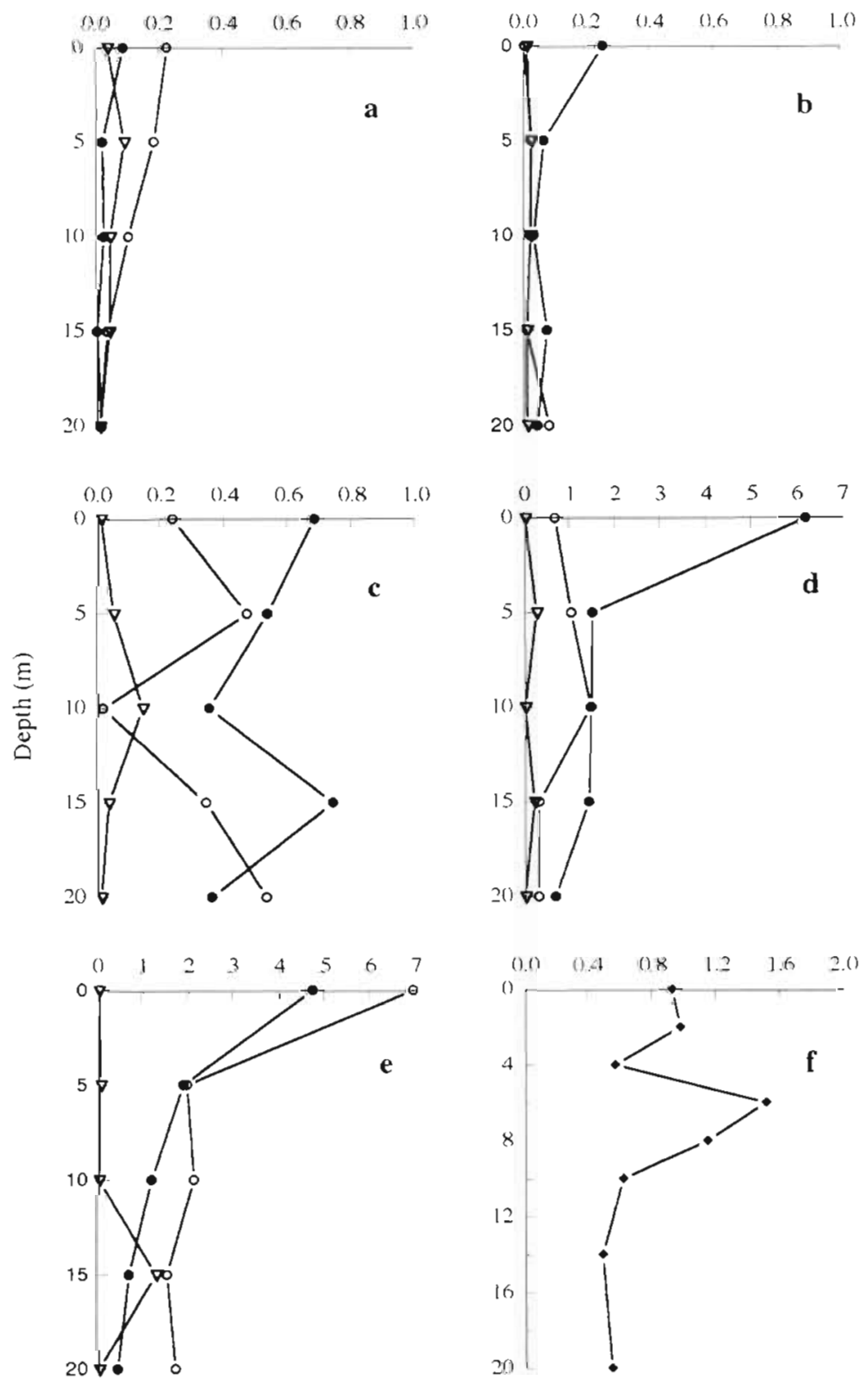

Fig. 11. Profiles of primary productivity (PP) in different size fractions ( $\bullet$ $>10 \mu \mathrm{m} ; \mathrm{o}: 2$ to $10 \mu \mathrm{m} ; \mathrm{\nabla}:<2 \mu \mathrm{m}$ ) in (a) January, (b) February. (c) March, (d) April, (e) June and (f) October 1992

autumn freshets. The reasons were a comparatively smaller quantity of freshwater, as well as their faster spreading over a stratified water column. Moreover, during this period nutrients with high $\sum \mathrm{N}_{\mathrm{in}} / \mathrm{Si}$ were introduced into the Gulf since rain water in the area is characterised by a high $\sum \mathrm{N}_{\mathrm{in}} / \mathrm{Si}$ ratio (>35). By contrast, river water ratios are in the range of 1 to 3 with an average of $1.3 \pm 0.8$ (V. Turk unpubl.). Thus, the situation in late spring was favourable for the development of small flagellates in the 2 to $10 \mu \mathrm{m}$ size range. High surface productivity and an accumulation of biomass in June was largely due to Prymnesiophytes, as evidenced by chemotaxonomic pigment signatures (19'hex; Arpin et al. 1976, Rowan 1990). The $>10 \mu \mathrm{m}$ fraction consisted mainly of dinoflagellates (genera Prorocentrum, Ceratium and Dinophysis). Among diatoms only small Chaetoceros species (e.g. C. affinis v. wilei) and to lesser extent Cyclotella sp. were present in notable numbers. Chl a-specific total productivity of surface samples was

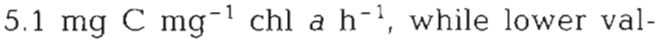
ues for the $>10 \mu \mathrm{m}$ fraction $12.6 \mathrm{mg} \mathrm{C} \mathrm{mg}^{-1}$ chl $a \mathrm{~h}^{-1}$ ) mirrored the lower photosynthetic rates and slower specific growth rate of dinoflagellates (Chan 1980), which dominated this size fraction. As vertical stratification persisted through summer and a low nutrient environment was maintained in the surface layer, phytoplankton biomass above the pycnocline decreased. Bottom phytoplankton was also dominated by cells $<10 \mu \mathrm{m}$ from July to September. Pigment composition of the bottom community showed the prevalence of 19'-hex (Prymnesiophytes) and chl $b$ (green algae) over fucoxanthin (diatoms). In spite of significant silicate concentrations in the bottom layer (Fig. 3b), diatoms constituted only a minor fraction $(<20 \%)$ of the phytoplankton, indicating that flagellates were more successful in this environment. Contrary to our results, in the conditions prevailing in the Bay of Brest, France (Ragueneau et al. 1994), the benthic regeneration of silica induced a shift towards a higher diatom: dinoflagellate ratio during late spring.

Diatoms generally have higher cell division rates than similar-sized microflagellates under non-limiting nutrient conditions (Furnas 1990). However, the growth of flagellates appears to be less affected by low nutrient concentrations, presumably due to their motility which increases nutrient encounter (Egge \& Aksness 1992). This enables flagellates to outcompete diatoms in nutrient-deficient environments despite sufficient silicate concentrations. Besides flagellates, prokaryotic picoplankton comprised an important part of the phytoplankton in summer, reaching annual peaks both in surface as well as bottom layer in September (Turk 1992).

To obtain further evidence of nutrient limitation of summer surface phytoplankton, we carried out a series of nutrient enrichment experiments in which we mea- 
sured ${ }^{14} \mathrm{CO}_{2}$ fixation and chl a biomass following different combinations of nutrient additions relative to controls with no additions. Results are described in detail elsewhere (Turk et al. 1994), and for the purposes of this paper the results are summarised as follows. Single nutrient additions (nitrogen as nitrate + ammonium, silicate and phosphate) had no effect on either biomass accumulation or the carbon fixation rate. Summer phytoplankton was stimulated only by a mixture of all nutrients. All size fractions were stimulated, but the most pronounced biomass increase was observed in the $>10 \mu \mathrm{m}$ fraction. Diatoms Rhizosolenia delicatula, Skeletonema costatum and Chaetoceros spp., which had low abundances in initial samples, responded most strongly to nutrient additions. Similar experiments were conducted in October and November. Phytoplankton productivity and biomass were also stimulated by a mixture of all nutrients in October. In contrast, after the October-November freshet, which introduced new nitrogen and silicate into the Gulf, the most pronounced increase was found for phosphorus addition.

A comparison of phytoplankton dynamics as related to freshwater inputs in the Gulf of Trieste and the Northern Adriatic has shown a great deal of similarity. Gilmartin et al. (1990) concluded that the spring river nutrient load from the Po River was the most important factor establishing the annual trophic level of the Northern Adriatic ecosystem. The spring bloom following increased Po River discharge is usually dominated by microplanktonic diatoms (Revelante \& Gilmartin 1976), with Skeletonema costatum and Nitzschia spp. as dominant species, while during the stratified summer period, microplankton contributed only from 25 to $35 \%$ of the total phytoplankton carbon (Revelante \& Gilmartin 1992). These results are in agreement with our observations in the Gulf of Trieste which indicated the predominance of the 2 to $10 \mu \mathrm{m}$ size fraction and the importance of Prymnesiophytes as identified by the taxonomic pigment biomarker 19'-hex.

In summary, the freshwater-borne nutrient inputs were the predominant factor determining phytoplankton dynamics in small semi-enclosed coastal waters of the Gulf of Trieste. Both phytoplankton standing crop and community structure were shown to be strongly influenced by the freshets and to a lesser extent by short-lived freshwater pulses such as storms. Among various size classes of phytoplankton the strongest response was found for the $>10 \mu \mathrm{m}$ fraction as reflected both in pigment biomass and chl aspecific productivity. The agreement of our data in the Gulf of Trieste with those obtained on a larger system indicates that small systems may be suitable for predicting general phytoplankton dynamics in temperate coastal waters that receive significant freshwater discharges.
Acknowledgements. The research was supported by Ministry of Science and Technology, Ministry of Environment and Regional Planning of the Republic of Slovenia, Ministry of Science, Technology and Informatics of the Republic of Croatia, and The Observatory of the Northern Adriatic. We are grateful to the technicians participating in the Alps-Adria project for their valuable help in sampling, analyses, data elaboration, and to the researchers for their discussions. Special thanks to Janez Forte for data elaboration and figure drawing.

\section{LITERATURE CITED}

Anon. (1985). Water Management Institute Report. Water Management Institute, Ljubljana

Arpin, N., Svec, W. A., Liaaen-Jensen, S. (1976). New fucoxanthin-related carotenoids from Coccolithus huxleyi. Phytochem. 15: 529-532

Barlow, R. G., Mantoura, R. F. C., Gough, M. A., Fileman, T. W. (1993). Pigment signatures of the phytoplankton composition in the northeastern Atlantic during the 1990 spring bloom. Deep Sea Res. 40:459-477

Boyer, J. N., Christian, R. R., Stanley, D. W. (1993). Patterns of phytoplankton primary productivity in the Neuse River estuary, North Carolina, USA. Mar. Ecol. Prog. Ser. 97: $287-297$

Chan, A. T. (1980). Comparative physiological study of marine diatoms and dinoflagellates in relation to irradiance and cell size. II. Relationship between photosynthesis, growth, and carbon/chlorophyll a ratio. J. Phycol. 16: $428-432$

Degobbis, D. (1988). Biogeochemical cycle of nutrients in the northern Adriatic Sea. Ph.D. thesis, University of Zagreb, Ruð̃er Bošković Institute

Degobbis, D., Fonda Umani, S., Franco, P., Malej, A., Precali, R., Smodlaka, N. (in press). Changes in the northern Adriatic ecosystem and the hypertrophic apprearance of gelatinous aggregates. Sci. Tot. Environ.

Degobbis, D., Gilmartin, M. (1990). Nitrogen, phosphorus, and biogenic silicon budgets for the northern Adriatic Sea. Oceanol. Acta 13: 31-45

Dortch, Q., Whitledge, T E. (1992). Does nitrogen or silicon limit phytoplankton production in the Mississippi River plume and nearby regions? Cont. Shelf Res. 12(11): 1293-1309

Egge, J. K., Aksness, D. L. (1992). Silicate as regulating nutrient in phytoplankton competition. Mar. Ecol. Prog. Ser. 83: $281-289$

Fisher, T R., Harding, J. W. Jr, Stanley, D. W., Ward, L. G. (1988). Phytoplankton, nutrients, and turbidity in the Chesapeake, Delaware, and Hudson esturies. Estuar. coast. Shelf Sci. 27: 61-93

Fisher, T R., Peele, E. R., Ammerman, J W., Harding, L. W. Jr (1992). Nutrient limitation of phytoplankton in Chesapeake Bay. Mar. Ecol. Prog. Ser. 82: 51-63

Fonda Umani, S., Franco, P., Ghirardelli, E., Malej, A. (1992) Outline of oceanography and the plankton of the Adriatic Sea. In: Colombo, G., Ferrari, I., Ceccherelli, V U., Rossi, R. (eds.) Marine eutrophication and population dynamics. Olsen \& OIsen, Fredensborg, p. 347-365

Franco, P. (1973). L'influenza del Po sui caratteri oceanografici e sulla biomassa planctonica dell'Adriatico settentrionale. Ann. Univ. Ferrara 1 (Suppl. 1): 95-117

Furnas, M. J. (1990). In situ growth rates of marine phytoplankton: approaches to measurement, community and species growth rates. J. Plankton Res. 12: 1117-1157 
Gallegos, C. L. (1992) Phytoplankton photosynthesis, productivity, and species composition in a eutrophic estuary: comparison of bloom and non-bloom assemblages. Mar. Ecol. Prog Ser. 81. 257-267

Gallegos, C. L., Jordan, T. E., Correll D. L. (1992). Event-scale response of phytoplankton to watershed inputs in a subestuary: timing, magnitude, and location of blooms. Limnol. Oceanogr. 37: 813-828

Gargas, E. (1975). A manual for phytoplankton primary production studies in the Baltic. In: Gargas, E. (ed.) The Baltic marine biologist, $p$ 1-88

Gilmartin, M., Degobbis, D., Revelante, N., Smodlaka, N. (1990). The mechanism controlling plant nutrient concentrations in the northern Adriatic Sea. Int. Rev. ges. Hydrobiol. 75: 425-445

Granéli, E., Wallström, K., Larson, U., Granéli, W., Elmgren, R. (1990). Nutrient limitation of primary production in the Baltic Sea area. Ambio 19(3): 142-151

Grasshoff, K. (1983). Methods of sea water analyses. Verlag Chemie, Weinheim

Harding, L. W. Jr (1994). Long-term trends in the distribution of phytoplankton in Chesapeake Bay: roles of light, nutrients and streamflow. Mar. Ecol. Prog. Ser. 104: 267-291

Jeffrey, S. W., Sielicki, M., Haxo, F. T (1975). Chloroplast pigment patterns in dinoflagellates. J. Phycol. 11: 374-384

Jordan, T E., Correll, D. L., Miklas, J., Weller, D. E. (1991). Long-term trends in estuarine nutrients and chlorophyll, and short-term effects of variation in watershed discharge. Mar. Ecol. Prog. Ser 75: 121-132

Mallin, M. A., Paerl, H. W., Rudek, J., Bates, P. W. (1993). Regulation of estuarine primary production by watershed rainfall and river flow. Mar. Ecol. Prog. Ser. 93: 199-203

Malone, T., Crocker, L. H., Pike, S. E., Wendler, B. W. (1988). Influences of river flow on the dynamics of phytoplankton production in a partially stratified estuary. Mar. Ecol. Prog. Ser. 48: 235-249

Mantoura, R. F. C., Llewellyn, C. A. (1983). The rapid determination of algal chlorophyll and carotenoid pigments and their breakdown products in natural waters by reversephase high-performance liquid chromatography. Analyt. Chim. Acta 151: 297-314

Marchetti, R., Provini, A., Crosa, G. (1989). Nutrient load car-

This article was submitted to the editor ried by the River Po into Adriatic Sea, 1968-87 Mar Pollut. Bull. 20: 168-172

Olıvotti, R., Faganeli, J., Malej, A. (1986a). Impact of organic pollutants on coastal waters, Gulf of Trieste. Wat. Sci. Technol. 18: 57-68

Olivott, R., Faganeli, J., Malej, A. (1986b). Eutrophication of coastal waters, Gulf of Trieste. Wat. Scl. Technol. 18: $303-316$

Preisendorfer, R. V (1986). Secchi disc science: visual optıcs of natural waters. Limnol. Oceanogr. 31: 909-926

Radach, G. (1992). Ecosystem functioning in the German Bight under continental nutrient inputs by rivers. Estuaries $15(4): 477-496$

Ragueneau, O., De Blas Vareal, E., Tréguer, P., Quéguiner, B., Del Amo, Y (1994). Phytoplankton dynamics in relation to the biogeochemical cycle of silicon in a coastal ecosystem of western Europe. Mar. Ecol. Prog. Ser. 106: 157-172

Revelante, N., Gilmartin, M. (1976). The effects of Po River discharge on phytoplankton dynamics in the Northern Adriatic Sea. Mar. Biol. 34: 259-271

Revelante, N., Gilmartin, M. (1992). The lateral advection of particulate organic matter from the Po Delta region during summer stratification, and its implications for the Northern Adriatic. Estuar. coast. Shelf Sci. 35: 191-212

Rowan, K. S. (1990). Photosynthetic pigments of algae. Cambridge University Press, Cambridge

Smodlaka, N. (1986). Primary production of the organic matter as an indicator of the eutrophication in the northern Adriatic Sea. Sci. Tot. Environ 56: 211-220

Steeman Nielsen, E. (1952). The use of radioactive ${ }^{14} \mathrm{C}$ for measuring organic production in the sea. J Cons. perm int. Explor. Mer 18: 117-140

Turk, V. (1992). The microbial food web: time scales and nutrient dynamics in the Gulf of Trieste. Ph.D. thesis, University of Umea

Turk, V., Mozetič, P., Malačič, V., Malej, A. (1994). Significance of episodic inputs of nutrients by rainfall for phytoplankton production and biomass in the Gulf of Trieste. 29th Eur. Mar. Biol. Symp., Vienna, Abstracts

Utermöhl, H. (1958). Zur Vervollkommnung der quantitativen Phytoplankton-Methodik. Mitt. int. Verein. theor, angew. Limnol. 9: 1-38

Manuscript first receuved: July 26, 1994

Revised version accepted: December 27, 1994 